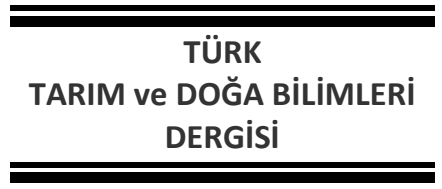

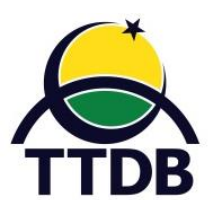

www.dergipark.gov.tr/turkjans Araştırma Makalesi

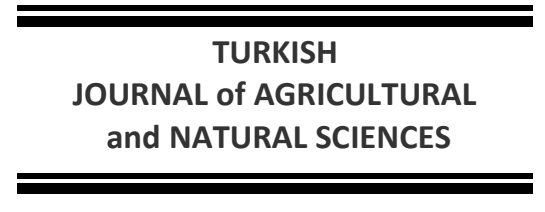

TURKISH

and NATURAL SCIENCES

\title{
Tarım İşletmelerinin Yönetiminde Kullanılan Tarımsal Bilgi Kaynakları: Kırşehir ilii Örneği
}

\author{
Halil Özcan ÖZDEMiR ${ }^{1^{*}}$, Mustafa KAN $^{1}$ \\ ${ }^{1}$ Kırşehir Ahi Evran Üniversitesi Ziraat Fakültesi Tarım Ekonomisi Bölümü, Kırşehir \\ *Sorumlu Yazar: hoozdemir@ahievran.edu.tr
}

Geliş Tarihi: 18.02.2020 Düzeltme Geliş Tarihi: 03.04.2020 Kabul Tarihi: 06.04.2020

\section{Özet}

Türkiye tarım sektörünün oluşturduğu değer büyüklüğü açısından Dünyada sayılı ülkeler arasında yer almaktadır. Bu kadar büyük değere rağmen potansiyelini yeterince değerlendirememesinin en önemli nedeni tarımdaki yapısal sorunlarıdır. Etkin bir örgütlerinin olmaması nedeni ile örgütsel bağlılıklarının düşüklüğü, girişimcilik ve inovasyon konusunda yeterli ortamın oluşturulamamış olması, tarımsal üretici gelirlerindeki aşırı dalgalanma ve belirsizlikler, öğrenim seviyesinin düşüklüğü, tarımda yaşlanma, sosyal güvenlik, gibi unsurlar tarım işletmesinde tarımsal işlerinin yönetimini olumsuz etkilemektedir. Bunun yanı sıra tarımda uzmanlaşma ve bu uzmanlaşmanın tabana yansımaması yani üretici-araştırıcı köprüsündeki kopukluk ve güvensizlik üreticileri informal bilgi kaynaklarına yöneltmektedir. Kırşehir ilinde (Toplam 7 ilçede) 304 tarım işletmesi yöneticisi ile yapılan bu anket çalışmasında tarım işletme yöneticilerinin tarımsal işleri yönetmesinde kullandıkları tarımsal bilgi kaynakları ve bu kaynakların seçiminde etkili faktörler incelenmiştir. Çalışma sonucunda, tarımda halen gelenekselci yaklaşımların ağılığını koruduğu, tarımda yaşlanma problemi ve artı değer oluşturacak yeterli ortamın olmaması nedenlerine bağı olarak üreticilerin bilgi kaynakları seçiminde halen informal kaynakları seçtikleri belirlenmiştir. Özellikle geliri olumlu yönde etkileyecek değişkenler tarımda işletme yöneticilerini formal bilgi kaynaklarına yöneltmektedir. Sonuç olarak Türkiye'de üreticilerin gereksinim duydukları tarımsal bilginin iyi yetişmiş uzman eller ile ulaştırılması amacı ile "Tarımsal Eğitim ve Yayım” çalışmalarında yapısal değişikliklere gidilmeli ve strateji, amaç ve hedeflerin belirlenerek bu hedeflere ulaşmak için yapısal reformlara ihtiyaç vardır.

Anahtar Kelimeler: Bilgi Kaynakları, Yönetim, Tarımsal Eğitim ve Yayım, Tarımsal Kalkınma

\section{Agricultural Information Sources for Management of Agricultural Enterprises: Kırşehir Province Case}

\begin{abstract}
Turkey, in terms of the value created by the agricultural sector is among the few important countries in the world. Despite such great value, the most important reason for not being able to use its potential sufficiently is the structural problems in the agriculture. Factors such as low organizational commitment due to lack of an effective organization, insufficient environment in entrepreneurship and innovation, excessive fluctuations and uncertainties in agricultural producer income, low education level, aging in agriculture, social security, etc., affect the management of agricultural affairs in the agricultural enterprise. In addition, the specialization in agriculture and not the reflection of this specialization to the bottom, that is, the disconnection and insecurity in the producer-researcher bridge, lead producers to informal information sources. In this survey, the study conducted with 304 agricultural enterprise managers in Kırşehir province ( 7 districts in total), the agricultural information sources used by the agricultural enterprise managers in managing agricultural works and the factors affecting the selection of these sources were examined. As a result of the study, it was determined that the traditionalist approaches in agriculture still prevail, and the producers still use informal sources in the selection of information sources due to the reasons for the aging problem in agriculture and the lack of sufficient environment to create surplus value. It directs agricultural holdings managers in agriculture to formal agricultural information sources, especially for variables that will positively affect income of them. As a result, Turkey should go to the structural changes in the work of "Agricultural Training and Extension" by the aim of delivering the agricultural information, which the producers need, with hands-on well-trained experts. For this, strategy, goals and targets should be determined and structural reforms should be made in order to reach the targets.
\end{abstract}

Keywords: Information Sources, Management, Agricultural Training and Extension, Agricultural Development 


\section{Giriş}

Örgütsel başarının elde edilmesi, sadece finansal ve fiziksel sermaye ile mümkün olmamaktadır. Örgütsel başarı elde edebilmek için sahip olunan işletme yönetiminde girişimcilere önemli görevler düşmektedir. Tarım işletmeleri için de durum bu şekildedir. Girişimcilerin işletmelerini yönetirken kullanacakları argümanları hangi kaynaktan edindikleri önemli bir faktör olarak karşımıza çıkmaktadır.

Cumhuriyetin kuruluşundan günümüze kadar ülkemizin ekonomik ve sosyal gelişiminde çok önemli görevler üstlenmiş olan tarım sektörü bundan sonra da önemli görevler üstlenmeye devam edecektir. Tarım; milli gelire ve istihdama katkısı, ülke nüfusunun beslenmesi, sanayiye sermaye aktarması, biyolojik çeşitlilik ile ekolojik dengeye olan katkıları ve ihracata doğrudan ve dolaylı katkısı gibi nedenlerle tüm dünyada vazgeçilmez olan ve gıda üretiminin güvenliği nedeniyle de büyük bir stratejik sektör özelliği taşır (Silsüpür, 2011; Doğan ve ark., 2015).Diğer sektörlerde olduğu gibi tarım sektörü de ülke ekonomilerini oluşturan temel sektörlerden biridir. Günümüzde tarım denildiğinde genellikle ilk aklımıza gelen kavram bitkisel üretimdir. Bu durum çok daha kapsamlı bir kavram olan tarımın hayvancılık, ormancılık ve su ürünleri gibi yönlerini eksik algılamaktan kaynaklanmaktadır (Olalı ve Duymaz, 1987).

Tarımsal alanda yapılan yeniliklerin yayım çalışmaları, gerek yeni bilgi ve teknolojilerin kaynağı olan üniversiteler ve araştırma kuruluşlarından alınarak onları kullanan çiftçilere iletilmesi, gerekse de çiftçilerin sorunlarına çözüm üretilmek amacıyla kaynağa iletilmesi açısından oldukça önem arz etmektedir (Taluğ ve Tatlıdil, 1993). Tarım ve hayvancılıkta etkili bir yayım sisteminin geliştirilmesi hususunda Tarım ve Orman Bakanlığı önemli görevler yürütmektedir. Tarım ve Orman Bakanlığı bünyesindeki Çiftçi Eğitimi ve Yayım Şubeleri aracılı̆ııla modern tarım ve hayvancılık teknolojilerinin kırsal alana yayılması ve yeniliklerin takipçilere benimsetilmesine çalışılmaktadır (Yalçın ve Boz, 2007). Ayrıca bu kurum tarım ve hayvancılık işletmelerinin mesleki eğitim düzeylerini yükselterek daha bilinçli tarım ve hayvancılık yapmaları için kırsal alanda çeşitli eğitim ve yayım hizmetleri düzenlemektedir.

Kırsal alanlardaki kalkınma süreci içerisinde tarımsal yayım çalışmaları önemli görevler intiva ederler. Tarımsal yayımın genel amaçlarını: tarımsal üretimde verimliliği arttırmak, doğal kaynakların korunması ve kullanımında etkinliği artırmak, pazarlama, dağııım ve tüketimde etkinlik sağlamak, üreticilerin kaynak geliştirmelerine katkıda bulunmak ve üretici ve ailesinin refah düzeyini artırmak faktörleri oluşturur (Özçatalbaş ve Gürgen, 1998; Yılmaz ve ark., 2009). Tarım kesiminde bilginin elde edilerek bu bilginin geliştirilmesi, paylaşılması ve kullanımı büyük öneme sahiptir. Tarımsal faaliyetlerde bilgi ve teknolojinin, tarımsal gelişmeyi hızlandırıcı ve yaşam seviyesini yükseltici bir rolü bulunmaktadır. Bu sebeple üreticilerin tarımsal üretimin gerçekleştirilmesi için bilgi kaynaklarını nasıl kullandıklarının bilinmesinin önemli olduğu belirtilmektedir (Röling, 1988).

Günümüzde tarım girdilerinin maliyetlerinin son derece artmış olması tarım işletmeleri yöneticilerini bu konu hakkında daha fazla düşündürmektedir. Daha düşük maliyetlerle daha yüksek miktarda üretim yapmak ve diğer işletmelerle rekabet edebilmek oldukça önemli bir sorun olarak karşımıza çıkmaktadır. Bu gibi meselelerin aydınlanmasında tarımda kullanılan bilgi kaynakları oldukça önemli bir konudur. Tarım işletmeleri yöneticileri işletmelerini yönetirken formal yani resmi bilgi kaynaklarından mı yoksa informal yani resmi olmayan bilgi kaynaklarından $\mathrm{m} ı$ faydalanmaktadırlar. Bu kaynağın marjinal fayda yaratacak şekilde belirlenmesi büyük önem taşımaktadır. Bu çalışmanın amacı tarım politikalarının yayımı noktasında ve tarımsal girişimcilerin işletmelerini yönetmeleri konusunda son derece önemli bir yere sahip olan bilgi kaynaklarının neler oldukları ve bu kaynakların hangilerinden ne miktarda faydalanıldığını belirlemek; bu doğrultuda yapılacak çalışmalara öncülük etmektir.

\section{Materyal ve Yöntem}

Bu çalışmanın materyalini, basit tesadüfî örnekleme yönetimi ile seçilen Kırşehir ilinde faaliyet gösteren ve Çiftçi Kayıt Sistemine (ÇKS) kayıtlı olan tarım işletmeleri yöneticilerinden elde edilen veriler oluşturmaktadır. Kırşehir ilinde 2019 yılı itibari ile ÇKS kayıtlarına göre toplam 19.934 adet tarım işletmesi bulunmaktadır. Çalışma Merkez ilçe dahil toplam 7 ilçede (Akçakent, Akpınar, Boztepe, Çiçekdağı, Kaman, Merkez Mucur) yürütülmüştür. Yapılan anketlerin hedefine ulaşılabilmesini sağlayabilmesi için tarım işletmesi yöneticileri "Ana Kitle Oranlarına Dayalı Basit Tesadüfî Örnekleme Yöntemi" ile seçilmiştir. Saha çalışmaları 2019 yııı Eylül-Aralık aylarında yapılmıştır. Örneklem sayısı, Tarım Ekonomisi literatüründe sonlu ana kitle için kullanılan aşağıdaki formül yardımıyla hesaplanmıştır (Yamane, 2010);

$$
\mathrm{n}=\frac{\mathrm{N} * \mathrm{p} *(1-\mathrm{p})}{(\mathrm{N}-1) * \sigma_{p}^{2}+\mathrm{p} *(1-\mathrm{p})}
$$

Formülde; $n=$ Örneklem hacmini, $N=A n a$ kitledeki birim sayısını, Ana kitledeki birim sayısı 
Kırşehir ilinde ÇKS'ye kayıtlı tarım işletmesi yöneticileridir (19.934 tarım işletmesi). p=Tarım işletmesi yöneticisinin formal ve informal bilgi kaynaklarına ulaşım oranı olup maksimum sayıda ankete ulaşabilmek için \%50 yani 0.50 olarak alınmıştır. q= Tarım işletmesi yöneticisinin formal bilgi kaynaklarına ulaşma olasılığı, 1-p $=0.50$ olarak alınmıştır. $\sigma_{p}^{2}$ : oranın varyansıdır. Gerçek ne olursa olsun istenen herhangi bir olasılık düzeyinde güven aralığının örnek oranının iki tarafında belli bir $r$ oranından daha fazla uzanmaması istenebilir. Bu durumda $\sigma_{p}^{2}$ parametresi;

$$
Z_{\alpha / 2} \sigma_{p}=r
$$

Olarak yazılabilir. Z tablo değeri $\% 5$ hata payı ile çalışılacağından 1.96 olarak alınmıştır. Formülde değerler yerine konulduğunda 273 adet anket yapılmasının çalışmadan sağlıklı sonuçlar elde edilmesi açısından uygun olacağı sonucuna varılmıştır.

Çalışmada tarım işletmeleri yöneticilerinin tarımsal faaliyetleri yürütme sırasında almış oldukları kararlarda etkili olabileceği düşünülen tarımsal bilgi kaynakları formal ve informal tarımsal bilgi kaynakları olarak 2'ye ayrılmıştır. Tarımsal bilgi kaynakları içerisinde işletme yöneticisinin kendi tecrübesi ile hareket etmesi, komşu, akraba, muhtar ve çevresinde gördüğü örnek çiftçilerden bilgi edinmesi, bilgi kaynağı olarak internet, TV gibi kitle iletişim araçlarını kullanması informal tarımsal bilgi kaynağı olarak, kamu sektörü (Kurum ve Kuruluşlaril/ilçe Tarım Müdürlükleri, Araştırma Enstitüleri, Üniversite), özel sektör (Tohum, Gübre, İlaç Bayileri vb), Kooperatifler-Birlikler-Odalar formal tarımsal bilgi kaynağı olarak ele alınmıştır. Tarım işletmesi yöneticilerine en önemli 3 tarımsal bilgi kaynakları sorulmuş ve 2 den fazla aynı gruptan tarımsal bilgi alanlar o gruba atanmıştır.

Tarım işletmesi yöneticilerinin tarımsal işlerin yönetiminde kullandığı tarımsal bilgi kaynakları seçiminde etkili olan faktörler 3 grup altında incelenmiştir. Toplam 16 değişkenin incelendiği çalışmada ele alınan değişkenler Çizelge 1 'de sunulmuştur. Çizelge 1 incelendiğinde ele alınan göstergeler sosyo-demografik, tarımsal ve gelirle ilgili göstergelerdir.

Çizelge 1. Çalışmada incelenen değişkenler

\begin{tabular}{|c|c|c|}
\hline Sosyo-Demografik Değişkenler & Tarımsal Değişkenler & Gelirle İlgili Değişkenler \\
\hline İşletme Yöneticisinin Yaşı (\%) & Mülk Arazi (MA) (Ha) & $\begin{array}{l}\text { İşletme Yöneticisinin Tarımsal } \\
\text { Gelirinin Toplam Gelir İçindeki Payı } \\
\text { (\%) }\end{array}$ \\
\hline Kuşaklar (\%) & Kiralık Arazi (KA) (Ha) & $\begin{array}{l}\text { İşletme Yöneticisinin Risk Alma } \\
\text { Davranışları }\end{array}$ \\
\hline $\begin{array}{l}\text { İşletme Yöneticisinin Öğrenim } \\
\text { Düzeyi (\%) }\end{array}$ & $\begin{array}{l}\text { Toplam İşlenen Kuru Arazi (TKA) } \\
\text { (Ha) }\end{array}$ & $\begin{array}{l}\text { İşletme Yöneticisinin Öznel } \\
\text { Yoksulluk Durumu }\end{array}$ \\
\hline $\begin{array}{l}\text { İşletme Yöneticisinin } \\
\text { Güvenlik Durumu (\%) }\end{array}$ & $\begin{array}{l}\text { Toplam İşlenen Kuru Arazi (TSA) } \\
\text { (Ha) } \\
\text { Toplam Arazi (TA) (Ha) } \\
\text { Sulu Arazi (SA)/Toplam Arazi (TA) } \\
\text { (\%) } \\
\text { Bitkisel Üretim Deneyimi (Yıl) } \\
\text { Hayvansal Üretim Deneyimi (Yıl) } \\
\text { Tarımda Çalışma Gün Sayısı (Gün) }\end{array}$ & \\
\hline
\end{tabular}

Verilerin analizinde uygun analiz türünün seçilmesi için verilerin homojen dağılıp dağılmadığı incelenmiştir. Verilerin normal dağılıma uygunluğunun belirlendiği yerlerde verilerin analizinde parametrik analiz yöntemlerinden t-testi, normal dağılıma uygun olmadığı durumlarda ise Mann-Whitney U ve Kolmogorov Smirnov Z testi ile analiz edilmiştir.

Tarımsal bilgi kaynakları ile oluşturulan formal ve informal tarımsal bilgi kaynakları grupları ile incelenen sosyo-demografik, tarımsal ve gelir değişkenleri arasında etkileşim olup olmadığını belirlemek için ki-kare $(\chi)$ ve G testi uygulanmıştır (Düzgüneş ve ark. 1993; Sokal and Rohlf, 1995). Elde edilen tablolarda beklenen frekansların 5 'den küçük olduğu hücre veya gözlerin, toplam hücre sayısının \%20'sini geçtiği durumlarda likelihood ratio (G istatistiği) değeri kullanılmıştır (Düzgüneş ve ark., 1993). Nitel değişkenler arasında ilişki olup olmadığının incelendiği ki-kare testinin esası parametrik hipotez testlerinde olduğu gibi $\mathrm{H}_{0}$ hipotezini ileri sürerek, bu hipotezin reddedilip edilemeyeceğini incelemektir (Serper, 1986). Ho hipotezinin reddedildiği yani bağımlılığın belirlendiği durumlarda bağımlılığın oranını belirlemek amacıyla Bağımlılık Katsayısı (Contingency Coefficient) kullanılmıştır (Özdamar, 2018).

\section{Bulgular ve Tartışma}


Tarım yapısı gereği diğer sektörlerle karşılaştırıldığında vazgeçilebilecek ya da ikinci sıraya konulabilecek bir sektör değildir. Tarımdan elde edilen gıda insanoğlunun ihtiyaçlar hiyerarşisi içerisinde ilk ve en önemli sırayı oluşturmaktadır. Dünyada yaşanan tarımsal krizlerin ortaya çıkardığı tablolar incelendiğinde etkisinin en geniş ve en derin olduğu sektör olduğunu söylemek yanlış olmaz. Bu nedenle bir ülkede tarımsal kalkınma ülkenin refahı ve mutluluğu için çözülmesi gereken sorunların başında gelmektedir.

Türkiye tarım sektörünün büyüklüğü ile dünyada en önemli ülkelerden biridir. Sektörün büyüklüğü kadar sektörün potansiyeli dikkate alındığında birçok çalışmada özellikle yapısal sorunları nedeni ile istenilen düzeyde olunmadığı belirtilmektedir (Özertan, 2013; Yavuz ve Dilek, 2019; Kan ve ark. 2020;). Bu yapısal sorunlar tarım sektöründe verimliliğe doğrudan ve dolaylı olarak etkilemekte birçoğunun nitel yapıda olması nedeni ile etkileri tam olarak belirlenememektedir. Özellikle üreticinin doğru bilgi ve tekniklere ulaşması konusundaki sıkıntılar bu yapısal problemlerden bir tanesi olarak gösterilebilir. Tarım söz konusu olduğunda uzmanlık yerini deneyimsel öğrenme yapısına bırakmakta ve tecrübesi olan daha fazla bilir sonucuna ulaştırmaktadır. Buda tarımda gelişmeyi ve kalkınmayı olumsuz etkilemektedir.
Kulaktan dolma bilgilerle, yaşanılan çevreden gelen tepki veya uyarılarla tarımsal faaliyetlerin yürütüldüğü, komşusunun uygulamalarına bakarak yapılacak işlemlerin planlandığı, bilimsel temelden uzak görsel veya yazılı kitle iletişim araçlarının yaptığı abartılı haberlerle girişimlerde bulunulduğu, piyasayı iyi okuyamayan, tarımsal bilgi düzeyi düşük, uzmanlık alanı çiftçilik olmayan, çiftçiliğin herkes tarafından yapılabileceğine inanan ve tarımın bir bilim dalı ve bu bilim dalının uzmanları olduğunu düşünmeyen bir kesim tarafından yürütülen tarımda başarıyı yakalamak hayal kurmanın ötesine geçememektir.

Araştırmanın temelini oluşturan Kırşehir ilinde tarım işletmelerinde bilgi kaynakları ve bu kaynakların seçiminde etkili olan bazı faktörlerin ortaya konulduğu bu çalışmada ÇKS'ye kayıtlı tarım işletmesi yöneticilerinin bilgi kaynakları önem sırasına göre Çizelge 2'de gösterilmiştir. Çizelge 2 incelendiğinde tarım işletmesi yöneticisinin işletmesinde tarımsal faaliyetlerin yönetimi ve organizasyonunda birincil bilgi kaynağı olarak informal kaynakları seçtiği görülebilir. İnformal bilgi kaynakları içinde de en önemli bilgi kaynağı yöneticinin kendi tecrübesi oluşturmaktadır. Aslında buradan Kırşehir ilinde tarım işletmeleri çalışmalarını dışarıdan hiçbir bilgi talep etmeden kendi içinde deneyimleri ile oluşturduğu bilgilerle hareket ederek yürüttüğü sonucuna ulaşılmaktadır.

Çizelge 2. Tarım işletmeleri yöneticilerinin işletmenin tarımsal faaliyetlerini yönetmesinde kullandıkları bilgi kaynakları

\begin{tabular}{|c|c|c|c|c|c|c|c|}
\hline \multicolumn{2}{|c|}{ Tarımsal Bilgi Kaynakları } & \multicolumn{2}{|c|}{$\begin{array}{l}\text { Birincil Tarımsal } \\
\text { Bilgi Kaynağı }\end{array}$} & \multicolumn{2}{|c|}{$\begin{array}{c}\text { İkincil Tarımsal } \\
\text { Bilgi Kaynağı }\end{array}$} & \multicolumn{2}{|c|}{$\begin{array}{l}\text { Üçüncül Tarımsal } \\
\text { Bilgi Kaynağı }\end{array}$} \\
\hline & & Sayı & $\%$ & Sayı & $\%$ & Sayı & $\%$ \\
\hline \multirow{7}{*}{$\begin{array}{c}\text { Informal Tarımsal } \\
\text { Bilgi Kaynakları }\end{array}$} & Kendi Tecrübesi & 253 & 83,22 & 0 & 0,00 & 0 & 0,00 \\
\hline & Eş/Dost/Akraba & 7 & 2,30 & 94 & 30,92 & 88 & 28,95 \\
\hline & Lider/Önder Çiftçiler & 2 & 0,66 & 20 & 6,58 & 75 & 24,67 \\
\hline & Muhtar & 0 & 0,00 & 20 & 6,58 & 42 & 13,82 \\
\hline & TV/Radyo/Internet & 0 & 0,00 & 0 & 0,00 & 41 & 13,49 \\
\hline & $\begin{array}{l}\text { Gazete/Dergi/Basılı } \\
\text { Kaynaklar }\end{array}$ & 0 & 0,00 & 0 & 0,00 & 8 & 2,63 \\
\hline & Toplam & 262 & 86,18 & 134 & 44,08 & 254 & 83,55 \\
\hline \multirow{5}{*}{$\begin{array}{l}\text { Formal Tarımsal } \\
\text { Bilgi Kaynakları }\end{array}$} & Tarım ve Orman Bakanlığı & 41 & 13,49 & 123 & 40,46 & 0 & 0,00 \\
\hline & Akademisyenler/Üniversite & 1 & 0,33 & 46 & 15,13 & 26 & 8,55 \\
\hline & Özel Sektör & 0 & 0,00 & 1 & 0,33 & 11 & 3,62 \\
\hline & Tarım Danışmanları & 0 & 0,00 & 0 & 0,00 & 13 & 4,28 \\
\hline & Toplam & 42 & 13,82 & 170 & 55,92 & 50 & 16,45 \\
\hline
\end{tabular}

İkincil bilgi kaynakları içerisinde formal ve informal bilgi kaynakları hemen hemen yarı yarıya bir paya sahip olup özellikle formal bilgi kaynaklarında Tarım ve Orman Bakanlığı il/ilcçe Tarım ve Orman Müdürlükleri başta gelmektedir (Çizelge 1). Tarımın devlet nezdinde yerel sahiplenicisi olan il/ilçe Tarım ve Orman Müdürlükleri gerek resmi prosedürlerin uygulanması gerekse üreticinin ihtiyacı olan bilginin sunulması açısından anahtar noktadır. Bu konuda tarımsal eğitim ve yayım faaliyetleri bu bilginin üreticiye ulaştırılmasında üzerinde öncelikle 
durulması gereken argümanların başında gelmektedir.

Üreticilerin üçüncül bilgi kaynaklarının büyük bölümünü yine informal bilgi kaynaklarının oluşturduğunun belirlendiği bu çalışmada elde edilen sonuçlar Türkiye'de tarımda informal bilgi kaynaklarının etkin olduğunu gösteren birçok çalışma ile benzerlik göstermektedir (Kızılaslan ve Kızılaslan, 1998; Boz ve ark., 2004, Oğuz ve ark., 2012; Hasdemir ve ark., 2014; Koksal ve ark., 2018).

Araştırma alanında tarım işletmesi yöneticilerinin tarımsal bilgi kaynaklarının seçiminde etkili olabileceği düşünülen bazı göstergeler ele alınmıştır. Bu göstergeler sosyodemografik, tarımsal ve gelirle ilgili göstergeler olarak 3 grup altında incelenmiştir. Sosyo demografik değişkenler içerisinde işletme yöneticisinin yaşı, kuşağı, öğrenim düzeyi ve sosyal güvence durumlarını gösteren değişkenler ele alınmıştır. Ele alınan değişkenler içerisinde yer alan işletme yöneticisinin yaşı önemli değişkenlerden biridir. Özellikle tarım işletmesi yöneticisinin yaşının artışı ile informal bilgi kaynakların kullanımının artabileceği düşünülmektedir. Şekil 1'de tarım işletmesi yöneticisinin yaşı ve bilgi kaynakları arasındaki ilişki gösterilmektedir. Şekil 1'den de görüleceği üzere tarım işletmesi yöneticisinin yaşı ile tarımsal bilgi kaynakları tercihi arasında yapılan $\mathrm{t}$ testi sonucu istatistiki açıdan önemli bir ilişki bulunamamıştır. Her iki bilgi kaynağını kullanan üreticilerin yaş ortalaması birbirine benzemektedir. Fakat buradaki en önemli gösterge tarım işletmeleri yöneticilerinin her iki grupta da 50 yaş ve üzeri olduğunun belirlenmesidir. 50 yaş Tarım Ekonomisi bilim dalında iş gücü hesaplarında yaşlı grubu oluşturmaktadır (Erkuş ve ark. 1995). Buradan Kırşehir ilinde tarım toplumunda yaşlanma ile ilgili bir durumun ortaya çıktığı söylenebilir.

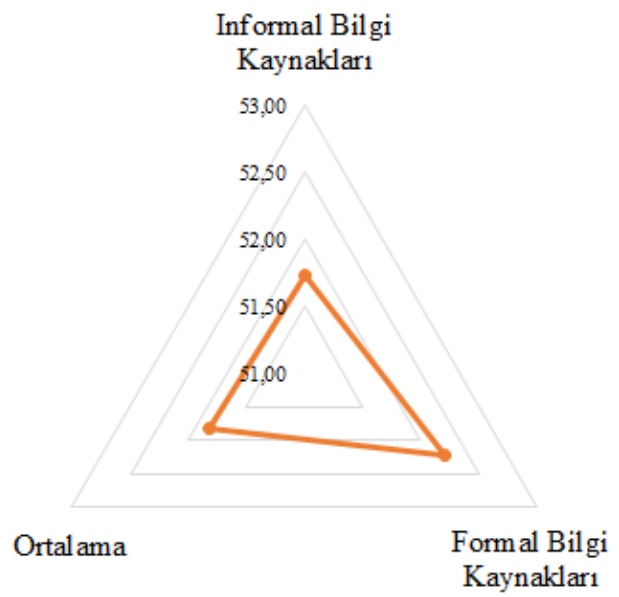

Şekil 1. Tarım işlemeleri yöneticilerinin yaşı ve tarımsal bilgi kaynakları arasındaki ilişki

Çizelge 3'de ele alınan diğer sosyodemografik değişkenler görülmektedir. Günümüzde en çok tartışılan hususlardan bir tanesi ise kuşaklar arası iletişimdir. Belirlenen kuşakların yapısal özellikleri ve içinde doğdukları toplumun genel özellikleri onların karar verme sürecinde davranışlarını etkilemesi beklenmektedir. Türkiye'de tarımsal faaliyetlerini yürüten tarım işletmelerinde "Baby Boomers" denilen kuşağın ağırlığı halen devam etmektedir. Türkiye'de özellikle kırsal alanda ve tarım sektöründe yaşlanma önemli bir sorun olarak karşımıza çıkmakta, sektörde $X$ ve $Y$ kuşağı bireylerin daha fazla yer alması gerektiği belirtilmekte ve buna yönelik politika tedbirleri alınmaktadır (Kan ve ark. 2018; Kan ve ark. 2019; Kan ve ark. 2020). Fakat kuşaklarla ilgili çalışmalarda yeni kuşak bireyinin eskisine oranla işten ve hayattan beklentisi daha yüksek olan, yaptıkları işten kolaylıkla sıkılabilen, çalışmayı çok sevmeyip otoriteye başkaldıran bireyler olduğu belirtilmektedir (Adıgüzel ve ark., 2014). Kuşaklar arası bu farklılıklar yeni kuşakların daha çok araştıran ve sorgulayan bir kesimin oluşturacağı yönünde sinyaller vermekte olup bu durumun tarım toplumu açısından da sorgulanması gerekmektedir. Çizelge 3 incelendiğinde Kırşehir ilinde tarım toplumunun yaklaşık \%6,25'inin Sessiz Kuşak ve \%35,86'sını Baby Boomer kuşağının oluşturduğu görülmektedir. Bu iki kuşağın toplamın diğer kuşakların oranlarından daha yüksektir. Kuşaklar arasında tarım işletmesi yöneticilerinin tarımsal bilgi kaynağı seçiminde farklılık olup olmadığı Ki-Kare Analizi ile incelenmiş ve yapılan analiz sonucu kuşaklara göre tarımsal bilgi seçiminde istatistiki olarak önemli bir farklılık bulunmamıştır. Buna göre tüm kuşaklarda tarımsal bilgi kaynakları içerisinde informal bilgi kaynakları ilk sırada gelmektedir. Kırşehir ilinde yapılan bu çalışma tarım toplumundaki gelenekselci yaklaşımın kuşaklar arası bir miras gibi devredildiğini göstermektedir. Sorgulayıcı, araştırıcı ve yeniliklere daha açık olması beklenen yeni kuşakların tarım toplumunda istenilen şekilde evrilmediği sonucuna ulaşılmıştır. Incelenen bir diğer değişken ise tarım işletmesi yöneticilerinin öğrenim düzeyidir. Öğrenim düzeyi ile insanların bilgi, algı ve bilinç düzeylerinin artması beklenmektedir (Kızılaslan ve Kızılaslan, 2005; Polat ve Dellal, 2016). Çalışmada beklenilen sonuç tarım işletmesi yöneticilerinin öğrenim düzeyi yükseldikçe formal bilgi kaynaklarını kullanma durumlarının artmasıdır. Çizelge 3 incelendiği tarım işletmesi yöneticilerinin öğrenim seviyesi ve bilgi kaynakları arasındaki istatistiki olarak anlamlı bir farklılık bulunmamıştır. Her öğrenim düzeyinde informal tarımsal bilgi kaynakları tercihi yüksektir. Buradaki sonucun nedeni iki unsura bağlanabilir. Birincisi Türkiye'de tarım toplumlarında öğrenim seviyesinin düşük olması nedeni ile öğrenim seviyesi farklılığın 
incelenmesi için yeterli büyükte işletmenin incelenmemiş olması, bir diğeri ise tarımla uğraşan kesimde yükseköğrenim seviyesine sahip olan bireylerin çoğunun (özellikle MYO ve Üniversite) tarım dışı alanlarda eğitim almış olmalarıdır. Son yıllarda tarım dışı uzmanlığa sahip birçok ön lisanslisans ve lisansüstü mezunu kişi gerek hobi, gerekse konojontüre bağlı değişen populizmin etkisi ile tarım sektörüne girerek kısa yoldan zengin olma hesabına girmektedirler. Bu bireyler tarım konusunda yeterince bilgi sahibi olmamalarına rağmen, bilimsel bilgi almak ve tarımı bilimsel çerçevede yapmak yerine çevresindeki bireylerin yaptıklarını kopya etmeyi tercih etmektedirler. Bu da tarım işletmesi yöneticilerinin öğrenim düzeyi ile bilgi kaynakları tercihi arasında istatistiki olarak önemli derecede farklı bir ilişkinin çıkmamasının sebeplerinden biri olabilir.

Çizelge 3. Tarım işletmeleri yöneticilerin sosyo-demografik özellikleri ve tarımsal bilgi kaynakları arasındaki ilişki

\section{Sosyo-Demografik Değişkenler}

\begin{tabular}{|c|c|c|c|c|c|c|}
\hline & \multirow{3}{*}{ Değişkenler } & \multicolumn{4}{|c|}{ Tarımsal Bilgi Kaynakları } & \multirow{3}{*}{$\begin{array}{l}\text { K-Kare } \\
\text { Değeri }\end{array}$} \\
\hline & & \multicolumn{2}{|c|}{ Informal } & \multicolumn{2}{|c|}{ Formal } & \\
\hline & & Sayı & $\%$ & Sayı & $\%$ & \\
\hline \multirow{4}{*}{ Kuşaklar } & 20-39 Yaş (Y Kuşağı) & 45 & 18,15 & 8 & 14,29 & \multirow{4}{*}{1,02} \\
\hline & 40-54 Yaş (X Kuşağı) & 101 & 40,73 & 22 & 39,29 & \\
\hline & 55-73 Yaş (Baby Boomer) & 86 & 34,68 & 23 & 41,07 & \\
\hline & 74-92 Yaş (Sessiz Kuşak) & 16 & 6,45 & 3 & 5,36 & \\
\hline \multirow{4}{*}{$\begin{array}{l}\text { Öğrenim } \\
\text { Düzeyi }\end{array}$} & Okuma Yazma Yok & 16 & 6,45 & 0 & 0,00 & \multirow{5}{*}{3,99} \\
\hline & Illkokul-ilköğretim & 168 & 67,74 & 42 & 75,00 & \\
\hline & Lise & 47 & 18,95 & 10 & 17,86 & \\
\hline & MYO-Üniversite & 17 & 6,85 & 4 & 7,14 & \\
\hline \multirow{3}{*}{$\begin{array}{l}\text { Sosyal } \\
\text { Güvenlik }\end{array}$} & Sosyal Güvencesi Yok & 38 & 15,38 & 0 & 0,00 & \\
\hline & BAĞKUR_Çiftçi & 89 & 36,03 & 24 & 42,86 & \multirow[t]{2}{*}{$9,85^{* * *}$} \\
\hline & Diğerleri & 120 & 48,58 & 32 & 57,14 & \\
\hline
\end{tabular}

*\%90, **\%95, ***\%99 Güven sınırında istatistiki olarak önemlidir.

Sosyo-demografik değişkenler arasında incelenen bir diğer değişken ise tarım işletmesi yöneticilerinin sosyal güvence durumudur. Tarımdaki en önemli yapısal sorunların başında sosyal güvence gelmektedir. Tarım sektöründe sosyal güvencesiz çalışma yaygındır. Tarımda kayıt dışı çalışmanın pek çok nedeni bulunmaktadır. Bunların başında çiftçilerin elde ettiği düşük gelirin prim ödemeye yetmemesi gösterilebilir (Karadeniz, 2006). Türkiye'de 2006 yılından bu yana tüm sosyal güvenlik kurumları tek bir çatı altında birleştirilmiştir (Alper, 2011). Fakat bireylerin sosyal güvenlik kurumlarına bu birleşmeden önceki girişleri emeklilik ile ilgili ayrımların yapılmasına neden olmaktadır. Bu kapsamda Türkiye'de tarım ile uğraşanların dahil olduğu sosyal güvence şemsiyesi BAĞKUR-Tarım olarak bilinmektedir. Araştırma bölgesinde tarım işletmesi sahiplerinin \%37,29'u BAĞKUR-Tarım olarak sosyal güvenceye sahip olup $\% 12,54$ 'inin sosyal güvencesi bulunmamaktadır (Çizelge 2). Türkiye'de tarım işletmeleri ile ilgili yapılan bazı çalışmalarda sosyal güvenlik kurumuna kayıtlı olma verilerinin çalışma ile benzerlik gösterdiği belirlenmiştir (Kızılaslan ve Adıgüzel, 2012; Oğuz ve ark. 2012). Tarım işletmelerinin yöneticilerinin sosyal güvenlik kurumuna kayıt durumu ile bilgi kaynakları arasındaki ilişki \%95 güven sınırında istatistiki olarak önemli olarak bulunmuştur. Sosyal güvencesi olmayan bireyler sosyal güvencesi olan bireylere göre daha fazla informal bilgi kaynaklarını tercih etmektedir. Bu da tarımda yapısal iyileşmede sosyal güvence durumunun önem arz ettiğini göstermektedir.

Araştırma alanında ele alınan bir diğer değişken grubu ise tarımsal göstergelerdir. Bu kapsamda tarım işletmesinin yönettiği işletmenin büyüklüğü konusunda bilgi veren arazi varlığı, arazi yapısı ve işletme yöneticisinin tarımsal deneyimleri dikkate alınmıştır. Ele alınan tarımsal değişkenlerin çoğu aynı zamanda arazi sermayesi içinde toprak sermayesini de oluşturmaktadır. İşletme genişliği konusunda bilgi veren bu değişkenlerin tarım işletmesi yöneticilerini tarımsal bilgi kaynaklarına göre değişip değişmediği incelenerek Çizelge 4'de ortaya konulmuştur. Çizelge incelendiğinde işletmenin işlediği arazi genişliği arttıkça tarım işletmesi yöneticilerinin formal bilgi kaynaklarına yöneldiği görülmüştür. Bunun yanı sıra işletme yöneticisinin bitkisel ve hayvansal üretimdeki deneyimleri bilgi kaynaklarının seçimi ile ilişkisi istatistiki olarak anlamlı bulunmamıştır. Bu durum deneyim değişkenlerinin yaş değişkeni ile yakın 
ilişkisi nedeni ile beklenen bir sonuç olduğunu söylemek yanlış olmaz.

Çizelge 4. Tarım işletmeleri yöneticilere ait tarımsal değişkenler ile tarımsal bilgi kaynakları arasındaki ilişki

\begin{tabular}{|c|c|c|c|}
\hline \multicolumn{3}{|c|}{ Tarımsal Değişkenler } & \multirow{3}{*}{$\begin{array}{c}\text { T test/ Kolmogorov- } \\
\text { Smirnov Z Test/Mann- } \\
\text { Whitney U test }\end{array}$} \\
\hline \multirow{2}{*}{ Değişkenler } & \multicolumn{2}{|c|}{ Tarımsal Bilgi Kaynakları } & \\
\hline & Informal & Formal & \\
\hline Mülk Arazi (MA) (Ha) & 10.27 & 19.89 & $5405,00 * * *(\mathrm{MWU})$ \\
\hline Kiralık Arazi (KA) (Ha) & 3.44 & 7.95 & $5742,50 * *(\mathrm{MWU})$ \\
\hline Toplam İşlenen Kuru Arazi (TKA) (Ha) & 11.07 & 22.46 & $5544,00 * *(\mathrm{MWU})$ \\
\hline Toplam İşlenen Sulu Arazi (TSA) (Ha) & 2.63 & 5.37 & $5745,00 * *(\mathrm{MWU})$ \\
\hline Toplam Arazi (TA) (Ha) & 13.70 & 27.83 & $4888,00 * * *(\mathrm{MWU})$ \\
\hline Sulu Arazi (SA)/Toplam Arazi (TA) (\%) & 2.02 & 2.93 & $5401,50 *(\mathrm{MWU})$ \\
\hline Bitkisel Üretim Deneyimi (Yıl) & 20.23 & 29.26 & $-1,35$ ( $T$ test) \\
\hline Hayvansal Üretim Deneyimi (Yıl) & 25.91 & 28.69 & $-0,31$ (T Test) \\
\hline Tarımda Çalışma Gün Sayısı (Gün) & 24.36 & 25.16 & $1,95 * * *(\mathrm{KSZ})$ \\
\hline
\end{tabular}

*\%90, **\%95, ***\%99 Güven sınırında istatistiki olarak önemlidir.

Çalışmada ele alınan bir değişken grubu ise tarım işletmesinin toplam geliri ile yakın ilişkisi olduğu düşünülen tarımsal gelirin payı, risk davranışı ve öznel yoksulluk değişkenleridir. Şekil 2'de tarımsal gelirin toplam gelirin içindeki oranı bilgi kaynaklarına göre dağılımı gösterilmektedir. Şekil incelendiğinde tarımsal gelirin toplam gelir içindeki oranı yüksek olan tarım işletmelerinin yöneticileri formal bilgi kaynaklarını daha çok seçmektedir. Bu farklılık aynı zamanda istatistiki olarak ta \%95 güven sınırında önemli olduğu belirlenmiştir. Elde edilen sonuç Türkiye'de tarım sektörü ile ilgili de önemli bir durumu göstermektedir. Yapılan çalışmada Kırşehir ilinde tarım işletmelerinin gelir kaynaklarının \%43,62'sini tarımsal gelir oluşturduğu görülmektedir. Tarım dışı gelirler daha fazla ön plana çıkmaktadır. Özellikle tarımdaki yaş ortalamasının yüksek olması emekli maaşı ilk sıralarda olmak üzere tarım dışı gelirin payını arttırmaktadır. Ortalama emekli yaş sınırı 55 olarak kabul edilirse yapılan çalışmada ele alınan örneğin \%38,82'ini 55 yaşın üzerindeki tarım işletmesi yöneticilerinden oluşmaktadır. Tarım sektöründe yer alan işletmelerin birçoğunda tarım dışı gelir önemli bir paya sahiptir. Bu konuda yapılan çalışmalar da araştırma bulgularımızı destekler niteliktedir (Karadavut ve ark., 2011; Oğuz ve Kan, 2011; Kan ve ark, 2016). Tarımsal gelirin toplam gelir içindeki oranının yüksek olduğu tarım işletmelerinde tarım işletmesi yöneticileri bilgi seçiminde daha hassas davranmaktadır. Bu nedenle bu işletmeleri doğru yönlendirecek bilgiler için formal bilgi kaynaklarını daha çok tercih ettiklerini söylemek yanlış olmaz.

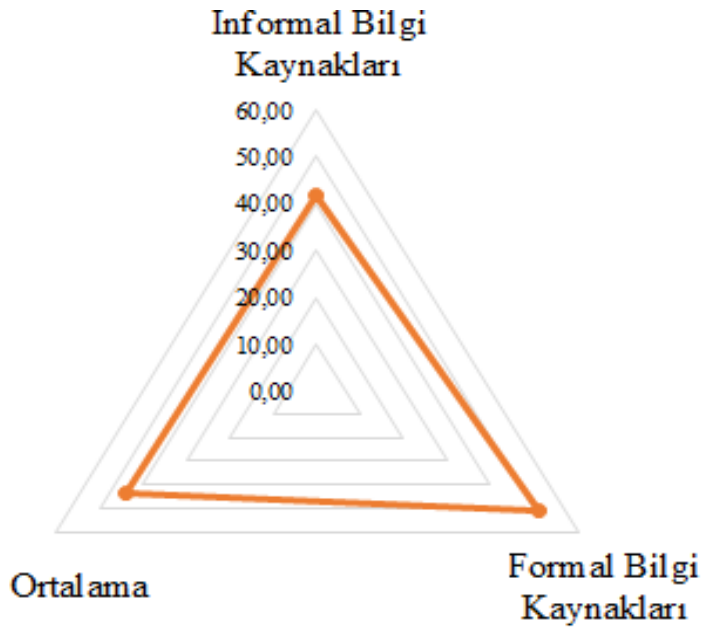

Şekil 2. Tarım işletmeleri yöneticilerin tarımsal gelir payları (\%) ile tarımsal bilgi kaynakları arasındaki ilişki (Mann-Whitney U test:5686,00, p:0,03)

Tarım girişimcilik ve buna bağlı olarak ta risk alma davranışları açısından diğer sektörlere göre farklılık göstermektedir. Belirsizliğin olduğu ve riskin arttığı durumlarda işletme sahipleri için karar almak çok daha zorlaşabilmektedir. Bunun bilincinde olan işletme sahiplerinin işletmelerini önceden belirledikleri amaçlar doğrultusunda yönetebilmeleri için belli bilgilere sahip olmaları gerekmektedir. Bu bilgilerde doğru bilgi kaynaklarından elde edilen güvenilir olmak zorundadır. Bu nedenle tarım işletmesi yöneticisinin risk davranışı ile bilgi kaynağı seçimi arasında bir ilişki olup olmadığı araştırılmış ve sonuçlar Çizelge 5'te sunulmuştur. 
Çizelge 5. Tarım işletmeleri yöneticilere ait gelir değişkenleri ile tarımsal bilgi kaynakları arasındaki ilişki

\begin{tabular}{|c|c|c|c|c|c|c|}
\hline \multicolumn{7}{|c|}{ Gelir Değişkenleri } \\
\hline & \multirow{3}{*}{ Değişkenler } & \multicolumn{4}{|c|}{ Tarımsal Bilgi Kaynakları } & \multirow{3}{*}{$\begin{array}{l}\text { Ki-Kare } \\
\text { Değeri }\end{array}$} \\
\hline & & \multicolumn{2}{|c|}{ Informal } & \multicolumn{2}{|c|}{ Formal } & \\
\hline & & Sayı & $\%$ & Sayı & $\%$ & \\
\hline \multirow{3}{*}{ Risk } & Riski Seven & 93 & 37,50 & 24 & 42,86 & \multirow{3}{*}{$4,59^{*}$} \\
\hline & Riske Duyarsız & 28 & 11,29 & 11 & 19,64 & \\
\hline & Riskten Kaçınan & 127 & 51,21 & 21 & 37,50 & \\
\hline \multirow{3}{*}{$\begin{array}{l}\text { Öznel } \\
\text { Yoksulluk }\end{array}$} & Yoksul & 14 & 5,65 & 0 & 0,00 & \multirow{3}{*}{$5,53^{*}$} \\
\hline & Orta & 188 & 75,81 & 40 & 71,43 & \\
\hline & İyi & 46 & 18,55 & 16 & 28,57 & \\
\hline
\end{tabular}

*\%90, **\%95, ***\%99 Güven sınırında istatistiki olarak önemlidir.

Çizelge 5 incelendiğinde riski seven tarım işletmesi yöneticilerinin büyük bir oranının formal, riskten kaçınanların ise informal bilgi kaynaklarını seçtiği görülmüştür. Aradaki ilişki ise istatistiki olarak \%90 güven sınırında önemli olduğu belirlenmiştir. Özdemir ve Kan (2020) Kırşehir ilinde tarım işletmeleri ilgili yaptıkları çalışmada İsletmelerin \%90,79'unun informal bilgi kaynaklarına başvurdukları ve bilgi kaynakları ile risk alma arasında istatistiki olarak önemli bir ilişki olduğunu belirlemişlerdir.

Kişinin kendisini yoksulluk açısından hissettiği durum olarak ta nitelendirilebilen öznel yoksulluk tarım işletmesinin hem geliri hem de refahı konusunda fikir vermektedir. Kırşehir ilinde tarım işletmelerinde tarım işletmeleri yöneticilerinin \%20,40'ı kendini öznel yoksulluk açısından iyi durumda olduklarını, \%75,00'ı ise orta düzeyde olduklarını belirtmişlerdir. Bu konuda çalışma yapan Oğuz ve ark. (2012) Konya ilinde tarım işletmelerinin yoksulluk konusunda yaptıkları çalışmada işletme sahiplerinin \%36,80'i kendilerini yoksul, \%49,38'i orta, \%13,82'si ise kendilerini iyi (zengin) olarak tanımlamışlardır.

Araştırma bulguları içinde öznel yoksulluk açısından durumlarını iyi olduklarını belirten tarım işletme yöneticilerinin daha fazla formal bilgi kaynaklarına başvurdukları görülmüş olup bu durum istatistiki olarak \%90 güven sınırında önemli olduğu belirlenmiştir (Çizelge 5). Öznel yoksulluk konusunda kendilerini iyi olarak belirten tarım işletmesi yöneticileri genellikle toplum içerisinde kendilerini önemli bir konumda ve lider pozisyonda görmektedirler. Bu pozisyonları onları toplum içinde takip eden değil takip edilen rolünü oynamaları yönünde yönlendirmektedir. Bu sınıftaki kişilerin hata yapma lüksünün olmaması onları daha fazla araştırma yapmalarına ve daha fazla formal kaynaklara yönelmelerine neden olmaktadır.

\section{Sonuç ve Öneriler}

Tarım sektörü gelişmiş, gelişmekte ve az gelişmiş ülkelerin hepsi için vazgeçilmez sektördür. Sanayi ve Hizmetler sektöründe büyük atılımlar yapan birçok gelişmiş ülke tarım sektörünü ikincil planda düşünmemiş büyüme ve kalkınma ile birlikte tarımsal büyüme ve kalkınmayı da beraberinde getirmiştir. Endüstri 4.0 gibi kavramlarla teknolojide gelinen son durumun açıklanmaya çalışıldığı günümüzde tarım da bu süreçte önemli oranda etkilenmiş ve tarımda geleneksel yapıdan çıkıp akıllı tarım teknolojilerinin kullanıldığı bir sürece evrilmiştir. Bu süreç tarımda bilgi kaynaklarının ne derecede önemli olduğunu göstermektedir. Küresel ısınma gibi önemli bir problemle karşı karşıya olan dünya toplumu, bu süreçte ortaya çıkan iklim değişikliğinin etkilerini minimize etmek için bilişim teknolojilerinin daha fazla kullanıldığı, karar destek sistemleri ile teknolojinin ileriye yönelik simülasyonlarla üreticiyi yönlendirdiği, çevreye duyarlı sürdürülebilir tarım sistemleri için optimizasyonun önemli olduğu ve bunun için uzman bilginin eskisinden daha çok ihtiyaç duyulduğu günümüzde tarım sadece veya çoğunlukla kulaktan duyma, atadan görme, gelenekselci bir yaklaşımla yürütülemez.

Yapılan bu çalışma sonucunda Kırşehir ilinde tarımda gelenekselciliğin halen ağır bastığı belirlenmiştir. Bunda tarım sektöründe yaşlanma ve halen Baby Boomer ve Sessiz Kuşakların toplamının genel içerisinde yoğun olarak yer almasının da etkisi büyüktür. Ayrıca Türkiye'de ziraat mühendisliği programlarından mezun olan bireyler yerine tarımda uzmanlık alanı dışında yer alan bireylerin popülist süreçlerin etkisiyle daha fazla yer alması da etkili olmaktadır. Sonuç olarak tarımda sorgulayan, araştıran, uzmanlık sahibi olmak için uğraşan, gündemi ve teknolojiyi takip eden ve bunu kendi tarım işletmesine uygulamaktan çekinmeyen bir 
tarım toplumu oluşturulmadığı sürece tarımda istediğimiz hedeflere sürdürülebilir olarak ulaşmamız zordur.

Geliri etkileyen gerek sosyo-demografik, gerekse tarımsal ve gelir ile ilgili değişkenler tarım işletmesi yöneticilerini bilgi kaynakları tercihinde formal kaynaklara yönelmesini etkilemektedir. Tarım sektöründe gelir düşüklüğünden ziyade gelirde büyük dalgalanmalar sektörü olumsuz etkilemektedir. Tarımsal üreticinin hakkının korunması için önemli yapısal değişikliklere ihtiyaç vardır. Üretici tüketici arasında oluşan aşırı fiyat marjlarından maalesef üretici yerine üretimle alakası olmayanlar daha çok yararlanmaktadır. Sadece üreticinin formal bilgi kaynaklarına yönelmesi yeterli olmayıp formal bilgi kaynakları içerisinde yer alan tarım uzmanlarının üreticinin ihtiyaçlarını karşılayacak, onlar için güvenilir ve yeterli olacak şekilde kendilerini yetiştirmeleri gerekmektedir. Tarım işletmeleri yöneticilerinin elinde bulundurdukları örgütlerini en iyi şekilde yönetebilmeleri; bunun sonucu olarak da verimlilik ve etkinliklerini arttırabilmeleri için Tarım ve Orman Bakanlığı tarafından yönetim ve organizasyon konusunda gerekli eğitimlerin kendilerine verilmesi gerekmektedir. Bu kapsamda tarımsal eğitim ve yayım faaliyetlerinin önemi iyice anlaşılmalı ve bu süreçte yer alan tarımsal eğitim ve yayım uzmanları iyi yetiştirilmelidir. Bu konuda Türkiye'de güncellenmiş, çağın gereklerine uyum sağlayan tarımsal eğitim ve yayım strateji belgesine ihtiyaç duyulmaktadır. Türkiye'de tarımsal yayım hizmetleri iyi planlanmalı ve üreticinin hizmetine sunulmalıdır.

\section{Kaynaklar}

Alper, Y. 2011. Kurumsal yapıda "Tek Çatı" hayata geçti. J. Soc. Pol. Con, (53): 141-171.

Boz, I.., Akbay, C. Orhan, E. ve Candemir, S. 2004. Çiftçilerin tarımsal faaliyetlerde kullandıkları bilgi kaynaklarının belirlenmesi ve tarımsal yayım açısından değerlendirilmesi. Türkiye $\mathrm{VI}$ Tarım Ekonomisi Kongresi, 16-18 Eylül 2004, Tokat s:596-603.

Doğan, Z., Arslan, S. ve Berkman, A. 2015. Türkiye'de tarım sektörünün iktisadi gelişimi ve sorunları: tarihsel bir bakış. Niğde Üniversitesi İktisadi ve İdari Bilimler Fakültesi Dergisi, 8(1): 29-41.

Düzgüneş, O., Kesici, T. ve Gürbüz, F., 1993. İstatistik Metodları, II. Baskı. Ankara Üniversitesi Ziraat Fakültesi Yayınları:369, Ankara.

Hasdemir, M., Hasdemir, M., Gül, U. ve Yaşan Ataseven, Z. 2014. Türkiye'de Jeotermal Seracılığın Mevcut Durumu ile Karar Verme Süreçlerinde Etkili Olan Faktörlerin Analizi. Tarımsal Ekonomi ve Politika Geliştirme Enstitüsü. TEPGE Yayın No: 227, Ankara.
Kan, M, Oğuz, C., Kan, A., Ergün, H. and Demiröz, E. 2018. Multidimensions of Poverty For Agricultural Community in Turkey: Konya Province Case. Pak. J. Agri. Sci., Vol. 55(1): 227-238.

Kan M., Kan A. ve Doğan H. G. 2018. Kırsal Alanda Tarımda Yaşlanmayı Önlemek İçin Genç Çiftçi Desteği Perspektifinden Bir Bakış. Uluslararası Katılımlı XIII. Ulusal Tarım Ekonomisi Kongresi, 1(1): 44-44.

Kan M., Tosun F., Kan A., Doğan H.G., Uçum I. and Solmaz C. 2019. Young Farmers in Agriculture Sector of Turkey: YoungFarmers Support Program. Journal of Agricultural Science and Technology, 21(1): 15-26.

Kan, M., Kan, A., Nizam, D., Perkin, A.Y., Everest, B. ve Taşçıŏlu, Y. 2020. Dünyada Ve Türkiye'de Kırsal Kalkınma Uygulamalarındaki Mevcut Durum ve Gelecek. TMMOB Ziraat Mühendisleri Odası, Türkiye Ziraat Mühendisliği IX. Teknik Kongresi, 13-17 Ocak 2020, Bildiriler Kitabı 2, s:687-710, Ankara.

Karadavut, U., Genç, A., Palta, Ç., Çarkacı, A. ve Kökten, K., 2011. Konya İli Yem Bitkileri Üreticilerinin Sosyo Ekonomik Yapıları İle Başarılı Üretimi Etileyen Faktörlerin Belirlenmesi, Bingöl Üniversitesi Fen Bilimleri Dergisi, 1(2):38-50.

Karadeniz, O. 2006. Türkiye'de çiftçilerin sosyal güvenliği ve sosyal güvenlik reformunun çiftçiler üzerine olası etkileri. DEÜ SBE, 8(4):91-127.

Kızılaslan, H. ve Kızılaslan, N. 2005. Çevre Konularında Kırsal Halkın Bilinç Düzeyi ve Davranışları (Tokat ili Artova illçesi Örneği). ZKÜ Sosyal Bilimler Dergisi 1(1):67-89.

Kızılaslan, N. ve Kızılaslan, H. 1998. Tokat ili Merkez ilçesinde yüksek sistem bağcılıkla uğraşan işletmelerde bilgi edinme kaynakları. JAFAG, 15(1):127-142

Kızılaslan, N. ve Adıgüzel, F. 2012. Tokat ili Merkez ilçede arı yetiştiricileri birliği üyelerinin birliğe örgütsel bağlılıklarının analizi. JAFAG, 29(1):13-27.

Koksal, O., Altunkaynak, B., Ataseven, Y. Cevher, C., Yasan Ataseven, Z., Gul Yavuz, G. and Gul, U. 2018. Evaluating Factors Affecting Farmers Information Sources in Agricultural Production Practices in Turkey. Journal of Environmental Protection and Ecology 19(1): 338-349.

Oğuz, C. ve Kan, A. 2011. Kırsal Alanda Tarım İşletmelerinde Yoksulluk ve Yoksulluğun Toplumsal Cinsiyet Çerçevesinde Değerlendirilmesi: Konya îli Hadim İlçesi Örneği. SOBAG-110K329. 
Oğuz, C., Ergun, H. Kan, A. ve Demiröz, E. 2012. Konya ilinde Kırsal Alanda Tarım İşletmelerinde Yoksulluk Analizi ve Uygun Stratejilerin Modellemesi. T.C. Gıda Tarım ve Hayvancılık Bakanlığı Ar-Ge Proje Sonuç Raporu TAGEM/09/AR-GE/12, Konya.

Olalı, H. ve Duymaz, i. 1987. Tarımın Türk Ekonomisindeki Yeri ve Ekonomik Gelişmeye Katkısı, İzmir, İzmir Ticaret Borsası Yayınları, Yayın No: 28.

Özçatalbaş, O. ve Gürgen, Y. 1998. Tarımsal Yayım ve Haberleşme. Adana, Baki Kitabevi.

Özdamar, K. 2018. Paket Programlar ile İstatistiksel Veri Analizi-1. Nisan Kitapevi, Eskişehir.

Özdemir, H.Ö. and Kan, A. 2020. Risk Behaviours of Agricultural Holdings Managers on Management and Decision Making Process in Agricultural Production; Kırşehir Province Case. J. Glob. Innov. Agric. Soc. Sci., 8 (1):3542.

Özertan, G. 2013. Türkiye Tarım Sektöründe Yapısal Dönüşüm ve Teknoloji Kullanımının Rolü. http://ideas.econ.boun.edu.tr/RePEc/pdf/2 01301.pdf

Polat, K. ve Dellal, i. 2016. Ramsar Alanlarda İyi Tarım Uygulamaları Yapan Üreticilerin İklim Değişikliği Algısı: Göksu Deltası Örneği. Tarım Ekonomisi Araştırmaları Dergisi, 2(1):51-62.
Röling, N. 1988. Extension Science Information Systems in Agricultural Development. Cambridge University Press, Cambridge.

Serper, Ö. 1986. Uygulamalı istatistik, Filiz Kitapevi, İstanbul.

Silsüpür, S. 2011. Tarım Sektörünün Türkiye Ekonomisine Katkısı, http:// www.ilgazetesi. com.tr/2011/06/25/tarım-sektörününTürkiye-ekonomisine-katkısı. (05.10.2011).

Sokal, R.R., and Rohlf, F.J. 1995. Biometry. The Principles and Practice of Statistics in Biological Research. Third Edition. W.H. Freeman Company. New York.

Taluğ, C. ve Tatlıdil, H. 1993. Tarımsal Yayım ve Haberleşme. Ankara Üniversitesi Ziraat Fakültesi Tarım Ekonomisi Bölümü Ders Notu, Teksir No: 141.

Yalçın, M. ve Boz, I. 2007. Kumluca ilçesinde seralarda üreticilerin kullandıkları bilgi kaynakları. Bahçe, 36(1-2), 1-10.

Yavuz, F. ve Dilek, Ş. 2019. Türkiye Tarımına Yeniden Bakış. SETA Siyaset, Ekonomi ve Toplum Araştırmaları Vakfı, SETA Yayınları 131, 1. Baskı.

Yılmaz, H., Demircan, V. ve Gül, M. 2009. Üreticilerin kimyasal gübre kullanımında bilgi kaynaklarının belirlenmesi ve tarımsal yayım açısından değerlendirilmesi. Ziraat Fakültesi Dergisi, 4(1): 31-44. 